\title{
A novel vascular endothelial growth factor-directed therapy that selectively activates cytotoxic prodrugs
}

\author{
RA Spooner,', , F Friedlos', K Maycroft ${ }^{2}$, SM Stribbling', J Roussel ${ }^{3}$, J Brueggen ${ }^{3}$, B Stolz ${ }^{3}$, T O'Reilly ${ }^{3}$, J Wood ${ }^{3}$, \\ A Matter ${ }^{3}$, R Marais ${ }^{2}$ and CJ Springer*, \\ 'Cancer Research UK Centre for Cancer Therapeutics at the Institute of Cancer Research, 15 Cotswold Road, Sutton, Surrey SM2 5NG, UK; ${ }^{2}$ Cancer \\ Research UK Centre for Cell and Molecular Biology at the Institute of Cancer Research, 237 Fulham Road, London SW3 6JB, UK; ${ }^{3}$ Novartis \\ Pharmaceutical AG, Pharmaceutical Research, CH-4002, Basel, Switzerland
}

We have generated fusion proteins between vascular endothelial growth factor (VEGF) and the bacterial enzyme carboxypeptidase G2 (CPG2) that can activate the prodrug 4-[(2-chloroethyl)(2-mesyloxyethyl)amino]benzoyl-L-glutamic acid (CMDA). Three asparagine residues of CPG2 were mutated to glutamine (CPG2(Q)3) to prevent glycosylation during secretion, and truncations of $V_{E G F}{ }_{165}$ were fused to either the $\mathrm{C}$ - or $\mathrm{N}$-terminal of CPG2. The $K_{m}$ of the fusion proteins $(37.5 \mu \mathrm{M})$ was similar to that of secreted CPG2(Q)3 (29.5 $\mu \mathrm{M})$ but greater than that of wild-type CPG2 $(8 \mu \mathrm{M})$. The affinity of the fusion proteins for VEGF receptor-2 (VEGFR2) $\left(K_{d}=0.5-1.1 \mathrm{nM}\right)$ was similar to that of $\left[{ }^{125}\right.$ I]VEGF $\left(K_{d}=0.5 \mathrm{nM}\right)$ (ELISA) or slightly higher $\left(K_{d}=1.3-9.6 \mathrm{nM}\right)(\mathrm{competitive}$ RIA). One protein, VEGF $115-C P G 2(Q) 3-H_{6}$, possessed $140 \%$ of the enzymic activity of secreted CPG2(Q)3, and had a faster halfmaximal binding time for VEGFR2 (77 s), than the other candidates (330 s). In vitro, VEGFII5-CPG2(Q)3-H 6 targeted CMDA cytotoxicity only towards VEGFR-expressing cells. The plasma half-life of VEGF $115-C P G 2(Q) 3-H_{6}$ in vivo was $3 \mathrm{~h}$, comparable to equivalent values observed in ADEPT. We conclude that enzyme prodrug therapy using VEGF as a targeting moiety represents a promising novel antitumour therapy, with $\mathrm{VEGF}_{115}-\mathrm{CPG} 2(\mathrm{Q}) 3-\mathrm{H}_{6}$ being a lead candidate.

British Journal of Cancer (2003) 88, I622- |630. doi:I0.1038/sj.bjc.66009। I www.bjcancer.com

(c) 2003 Cancer Research UK

Keywords: CPG2; VEGF; fusion proteins; targeting

Neoangiogenesis is critical for the growth, malignant progression, and metastatic spread of solid tumours and is effected by the release of angiogenic factors that are secreted by tumour cells (Fidler and Ellis, 1994; Folkman, 1995; Fukumura et al, 1998). One such angiogenic factor is vascular endothelial growth factor (VEGF) (Tischer et al, 1989). VEGF homodimers act by binding to two cell surface receptors (VEGFRs), known variously as VEGFR-1, flt-1, or fms-like tyrosine kinase, and VEGFR2, KDR, kinase insert domain-containing receptor, or $f l k-1$. Alternate splicing of the VEGF transcript results in the expression of five isoforms of VEGF, comprising molecules consisting of 208, 189, 165, 145, or 121 amino acids (Leung et al, 1989; Tischer et al, 1989; Houck et al, 1991; Poltorak et al, 1997). Of these, only the three smallest variants, $\mathrm{VEGF}_{165}, \mathrm{VEGF}_{145}$, and $\mathrm{VEGF}_{121}$, are secreted as soluble factors. Cell-surface-associated heparin-like molecules enhance the binding of VEGF to its receptors. Of the three soluble variants, $\mathrm{VEGF}_{165}$ and $\mathrm{VEGF}_{145}$ contain such heparin-binding domains whereas $\mathrm{VEGF}_{121}$ does not.

VEGFRs are highly expressed in areas of neoangiogenesis, such as in the endothelial cells of tumour vasculature, a restricted distribution that may be exploited to provide targeted therapy, using VEGF as a delivery molecule. Fusion proteins between VEGF and diphtheria toxin are indeed toxic to endothelial cells and to Kaposi's sarcoma cell lines, and inhibit angiogenesis, in a VEGFR-

*Correspondence: Prof CJ Springer; E-mail: caroline@icr.ac.uk Received 2 December 2002; revised 12 February 2003; accepted 25 February 2003 dependent manner (Arora et al, 1999). However, the disadvantage of such systems is that each protein molecule can affect only one cell. An alternative to diphtheria toxin is the use of an enzyme that can convert large numbers of molecules of a low molecular weight noncytotoxic prodrug to a cytotoxic drug. We have tested whether the bacterial enzyme carboxypeptidase G2 (CPG2, glutamate carboxypeptidase, E.C.3.4.17.11) can be fused to VEGF, to deliver a prodrug-activating enzyme to proliferating endothelial cells.

CPG2 hydrolyses several aromatic N-substituted glutamates to release benzoic acid, phenol, and aniline mustards (Springer, 1993; Springer et al, 1995); or when employing a self-immolative mechanism, can release other conventional therapeutic agents, such as anthracycline antibiotics (Niculescu-Duvaz et al, 1999). In this study, we used the noncytotoxic prodrug CMDA that releases L-glutamic acid and benzoic acid nitrogen mustard, a potent DNAalkylating agent (Figure 1). An advantage of alkylating agents is that they are cytotoxic to both cycling and noncycling cells (Frei et al, 1988; Teicher and Frei, 1988), such as would be found in tumours. CPG2 has previously been used in antibody-directed enzyme-prodrug therapy (ADEPT) in which it is targeted to tumours with tumour-specific antibodies (Bagshawe, 1990), an approach in clinical trial (Bagshawe et al, 1991; Napier et al, 2000). Similarly, expression of CPG2 tethered to the cell surface in genedirected enzyme-prodrug therapy (GDEPT) leads to extracellular prodrug activation (Marais et al, 1997), which in preclinical studies has been shown to generate a bystander effect, where neighbouring cells that do not express CPG2 are also killed (Stribbling et al, 2000). By analogy with ADEPT and GDEPT, VEGF-directed delivery of CPG2 will activate CMDA external to the cells and 


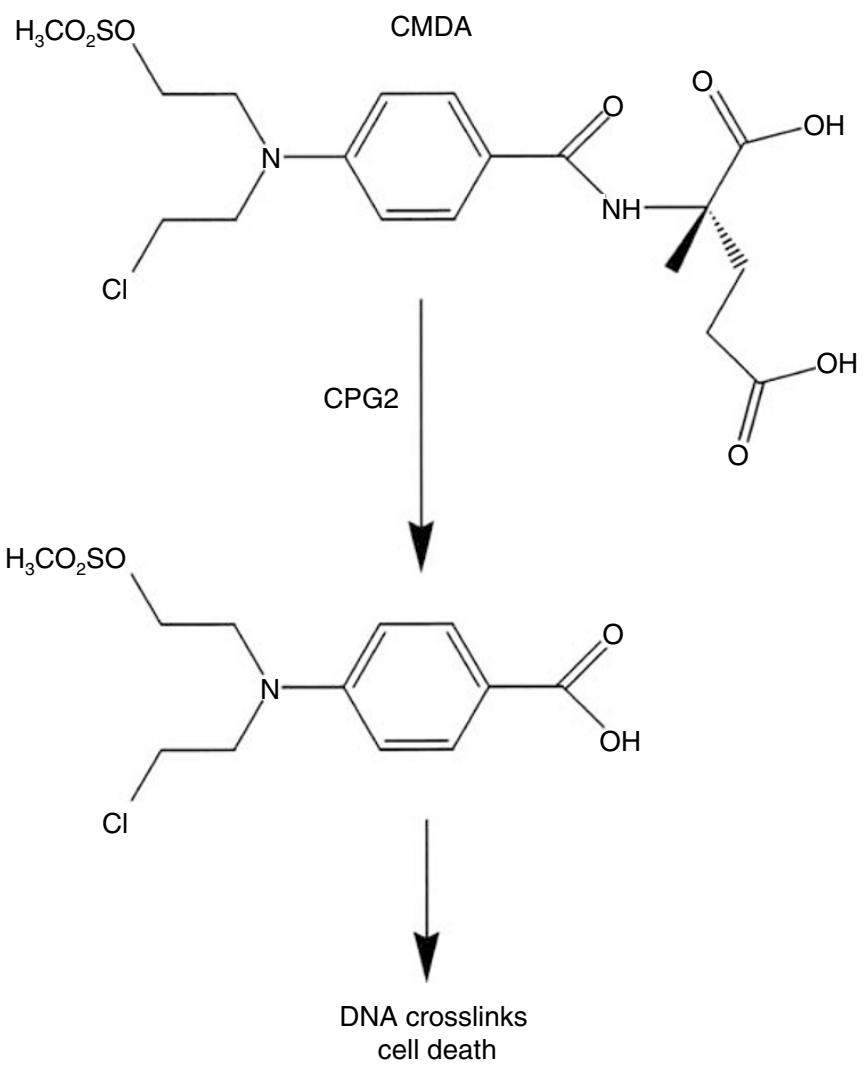

Figure I Activation of CMDA by CPG2. CPG2 cleaves the benzoic acid mustard prodrug 4-([2-chloroethyl][2-mesyloxyethyl]amino)benzoyl-L-glutamic acid (CMDA) to release L-glutamic acid and the mustard drug 4-([2chloroethyl][2-mesoxyethyl]amino)benzoic acid, a potent DNA-alkylating agent.

should also lead to killing of both target and bystander cells. The targeting of CPG2 to a tumour using VEGF will also cause destruction of the tumour vasculature and thus lead to significant levels of collateral damage with consequent ischaemic death of the tumour.

In this paper, we describe the construction, expression, and characterisation of a number of fusion proteins between VEGF and CPG2 that can bind to recombinant VEGFR2, and can differentiate between human umbilical vein endothelial cells (HU-V-EC) that express VEGFR2 and human ovarian adenocarcinoma cells (SKOV-3) that do not. Once bound, these proteins can convert CMDA to its toxic drug derivative and thereby kill the targeted cells. Further, we identify one construct, $\mathrm{VEGF}_{115}-\mathrm{CPG} 2(\mathrm{Q}) 3-\mathrm{H}_{6}$, with a combination of features that recommend it as a lead molecule for this targeted therapy, which we call Ligand-Directed Enzyme Prodrug Therapy or LiDEPT.

\section{MATERIALS AND METHODS}

\section{Construction of plasmids encoding fusion proteins}

All fusion genes were generated by PCR (Ho et al., 1989) and their sequences verified by automated DNA sequencing. For mammalian expression, constructs were cloned into the vector pEFPlink.2, which uses the elongation factor $1 \alpha(\mathrm{EF} 1 \alpha)$ promoter to direct expression in mammalian cells (19). For stable expression, the vector pMCEF - was used, which also uses the EF1 $\alpha$ promoter to direct expression, but additionally incorporates a neo ${ }^{\mathrm{R}}$ gene for clone selection (Marais et al, 1997).

\section{Expression and purification of fusion proteins}

Mammalian cells were transfected with expression plasmids using LipofectAmine, as previously described (Marais et al., 1997). Expression in insect cell vectors was achieved using the BaculoGold system (Pharmingen) as previously described (Marais et $a l, 1997)$. For small-scale protein extraction, detergent-soluble extracts were prepared as previously described (Marais et al, 1996), except that $\beta$-mercaptoethanol was omitted from all the buffers. For bulk protein production, $10^{8} \mathrm{Sf} 9$ insect cells were infected with fusion protein-encoding virus in a total of $100 \mathrm{ml}$ growth medium. The cells were grown in suspension for up to 9 days. Samples of growth medium $(100 \mu \mathrm{l})$ were monitored daily for CPG2 enzyme activity. When maximum yield was reached, the conditioned growth medium was filtered $(0.2 \mu \mathrm{m})$ and dialysed against $3 \times 5 \mathrm{l}$ $50 \mathrm{~mm}$ Tris- $\mathrm{HCl} \mathrm{pH} \mathrm{8,500} \mathrm{mM} \mathrm{NaCl}$ (column loading buffer), and $\mathrm{H}_{6}$-tagged proteins were purified by nickel-agarose chromatography, using standard protocols. The proteins were eluted with loading buffer containing $90 \mathrm{~mm}$ imidazole, and dialysed extensively against $100 \mathrm{~mm}$ Tris- $\mathrm{HCl} \mathrm{pH} 7.3,260 \mu \mathrm{M} \mathrm{ZnCl}$. The sample was adjusted to $10 \%$ final glycerol and stored at $-70^{\circ} \mathrm{C}$. CPG2 enzyme assays were performed using a standard assay. Briefly, samples containing CPG2 $(100 \mu \mathrm{l})$ were incubated in $900 \mu \mathrm{l} 100 \mathrm{~mm}$ Tris- $\mathrm{HCl} \mathrm{pH} 7.3,260 \mu \mathrm{M} \mathrm{ZnCl}{ }_{2}$ containing methotrexate (MTX, $55 \mu \mathrm{M})$, and activity was determined from the rate at which the absorbance at $320 \mathrm{~nm}$ declined. Immunoprecipitations were performed using standard approaches, using either a CPG2 polyclonal antibody (Hogg et al, 1987) or the 9E10 monoclonal antibody, which binds to the myc-epitope tag (Evan et al, 1985).

\section{Receptor binding studies and affinity measurements}

The apparent affinities of the fusion proteins for VEGFR2 were estimated by adapting a method of solid-phase immunoassay (Hogg et al, 1987). To measure the affinity of VEGF for the ligandbinding domain of VEGFR2, the binding to a construct in which the kinase domain was deleted (VEGFR2 $(\Delta \mathrm{KD}) \mathrm{m})$ was determined. Microtitre plates (96 well) were precoated with the $9 \mathrm{E} 10$ antibody $\left(20 \mu \mathrm{g} \mathrm{ml}^{-1}\right)$ and nonspecific sites were blocked with $3 \%$ skimmed milk powder in phosphate buffered saline (PBS) pH 7.4 containing $0.1 \%$ Tween-20 (PBS-T). Detergent extracts containing VEGFR2 $(\triangle \mathrm{KD}) \mathrm{m}$ were incubated overnight $\left(4^{\circ} \mathrm{C}\right)$ and the samples were incubated with $\left[{ }^{125} \mathrm{I}\right]$ VEGF (Amersham Biosciences, UK), followed by three washes with PBS-T and the amount of VEGF bound was determined by scintillation counting. The binding of the fusion proteins to VEGFR2 $(\triangle \mathrm{KD}) \mathrm{m}$ was determined as above, but using an ELISA format. Following binding of VEGFR2 $(\Delta \mathrm{KD}) \mathrm{m}$ to the antibody-coated microtitre plates, the samples containing the various fusion proteins were incubated with the complexes and the amount of fusion protein bound was measured by ELISA using a rabbit antiserum to CPG2 followed by anti-rabbit horseradish peroxidase and developed using the tetramethylbenzidine liquid substrate system (Sigma-Aldrich, UK).

Binding affinities were also estimated using a competitive displacement radiolabel receptor assay as previously described (Keyt et al, 1996) but substituting VEGFR2 $(\Delta \mathrm{KD}) \mathrm{m}$ for the KDRIgG fusion protein, and using the fusion proteins secreted from insect cells. The apparent dissociation constant $\left(K_{\mathrm{d}}\right)$ for each fusion protein was estimated from the concentration required for $50 \%$ inhibition of binding of $\left[{ }^{125} \mathrm{I}\right] \mathrm{VEGF}$ to immobilised VEGFR2 $(\Delta \mathrm{KD}) \mathrm{m}$.

\section{Synthesis of CMDA}

CMDA prodrug was synthesised as described previously (Springer, 1993). It was prepared as a $100 \mathrm{~mm}$ solution in DMSO immediately prior to use. 


\section{Cytotoxicity studies}

Human umbilical vein endothelial cells (HU-V-EC) were obtained from the American Tissue Culture Collection (ATCC) and were maintained in CS-C medium (Sigma-Aldrich, Missouri, USA), supplemented with $10 \%$ fetal calf serum and endothelial cell growth factor (Sigma-Aldrich, UK) according to the manufacturer's recommendations. Human ovarian adenocarcinoma SKOV-3 cells were maintained in Dulbecco's modified Eagle's medium supplemented with $10 \%$ fetal calf serum.

To determine their inherent sensitivity to CMDA, HU-V-EC and SK-OV-3 cells were seeded $\left(3 \times 10^{5}\right.$ cells well $\left.^{-1}\right)$ in six-well tissue culture plates. After 2-day growth, the cells were incubated for $19 \mathrm{~h}$ with $8000,4000,2000,1000,500,250$, or $125 \mu \mathrm{M}$ CMDA that had been diluted in appropriate growth medium. A proportion of the cells (approximately 30\% for HU-V-EC or approximately 3\% for SK-OV-3) were replated and allowed to grow for 5 days, when the surviving fraction was determined from the incorporation of $\left[{ }^{3} \mathrm{H}\right]$ thymidine $\left(0.4 \mu \mathrm{Ci} \mathrm{ml}^{-1}, 6 \mathrm{~h}\right)$.

For LiDEPT-dependent killing of the different cell lines, confluent monolayers of cells were exposed to varying concentrations of fusion proteins in complete growth medium $\left(37^{\circ} \mathrm{C}\right.$, $30 \mathrm{~min}$ ), followed by three washes with growth medium to remove unbound protein. The cells were then incubated in growth medium containing different concentrations of CMDA (19h) and cell survival determined as described above.

\section{In vivo stability studies}

All experiments were conducted in accordance with the United Kingdom Co-ordinating Committee on Cancer Research guidelines (Workman et al., 1998). A group of $18 \mathrm{BALB} / \mathrm{C}$ nude mice was injected i.p. with 50 units of $\mathrm{VEGF}_{115} \mathrm{CPG} 2(\mathrm{Q}) 3-\mathrm{H}_{6}$ in $200 \mu \mathrm{l}$ PBS. At intervals of $4,8,12,16,20,24 \mathrm{~h}$ after injection, triplicate blood samples were collected, and the CPG2 enzymic activity in the samples determined by assay against the model substrate methotrexate as previously described (Stribbling et al, 1997)

\section{RESULTS}

\section{Construction of fusion proteins between VEGF and CPG2}

Since CPG2 is a highly versatile protein, two classes of fusion protein between VEGF and CPG2 were considered. VEGF was fused either to the N-terminus or to the C-terminus of CPG2. For these studies, the aim was for these proteins to be secreted, so that the structurally important disulphide bonds of VEGF could form with high efficiency in the oxidising environment of the endoplasmic reticulum, and for glycosylation of VEGF to occur. Therefore, all constructs were provided with signal peptides. For those fusions in which VEGF was fused to the N-terminus of CPG2, the VEGF signal peptide was employed. For those fusion proteins that had CPG2 in the N-terminal position, the c-erbB2 signal peptide was employed, as this approach was previously shown to direct CPG2 to mammalian secretory pathways (Marais et al, 1997). However, since CPG2 becomes glycosylated and consequently is inactivated in this pathway, a version of CPG2 (CPG2(Q)3) was used, in which all three glycosylation sites were mutated to prevent this event. The VEGF and CPG2(Q)3 were separated by either a nine amino-acid linker $\left(\mathrm{EF}(\mathrm{G})_{5} \mathrm{TA}\right)$ or a minimal linker (GS). A schematic diagram of the various constructs is shown in Figure 2, and a description of their amino-acid structures is provided in Table 1. The final four Cterminal amino acids of $\mathrm{VEGF}_{165}$ were deleted in $\mathrm{VEGF}_{161^{-}}$ CPG2(Q)3- $\mathrm{H}_{6}$ since they contain three positively charged residues, which, if incorporated between fused VEGF and CPG2(Q)3 moieties, might be subject to recognition and cleavage by serine proteases such as trypsin. $\mathrm{VEGF}_{109}$ arose accidentally as a PCRgenerated truncation of $\mathrm{VEGF}_{165}$, and was retained for study. $\mathrm{VEGF}_{115}$ was generated as a refinement of $\mathrm{VEGF}_{109}$, being truncated exactly at the junction of the heparin-binding domain. Finally, to facilitate purification, polyhistidine tags $\left(\mathrm{H}_{6}\right)$ were fused to the C-termini of a number of the constructs to allow purification by nickel-agarose chromatography. The observed relative masses of the constructs were determined from their electrophoretic

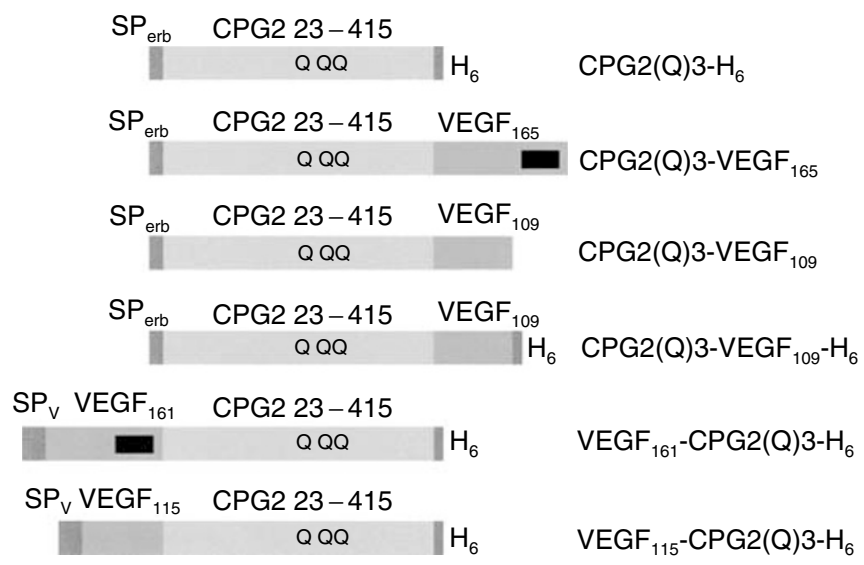

Figure 2 Schematic representations of the structures of CPG2 $(\mathrm{Q}) 3-\mathrm{H}_{6}$ and fusion proteins. $\mathrm{SP}_{\text {erb }}$ and $\mathrm{SP}_{\mathrm{v}}$ : signal peptides of c-erb $\mathrm{B} 2$ and VEGF, respectively. CPG2 23-4I5: amino acids 23-4I5 of CPG2, showing the relative positions of the three asparagine to glutamine mutations (Q) required to avoid glycosylation and concomitant loss of CPG2 activity. $\mathrm{H}_{6}$ oligohistidine tag for purification by nickel-agarose chromatography. $\mathrm{VEGF}_{165}, \mathrm{VEGF}_{109}, \mathrm{VEGF}_{115}$, and $\mathrm{VEGF}_{161}$ : amino acids I-165, 109, II5, and $|6|$, respectively, of $V E G F_{165}$. Black box: the relative position of the heparin-binding sequences of the longer forms of VEGF.

Table I Structures of the fusion proteins

\begin{tabular}{|c|c|c|c|}
\hline Protein & Predicted primary sequence & $M_{r}(e)$ & $M_{r}(0)$ \\
\hline $\begin{array}{l}\text { CPG2(Q)3-H } \\
\text { CPG2(Q)3-VEGF } 165 \\
\text { CPG2(Q)3-VEGF } 161-\mathrm{H}_{6} \\
\text { CPG2(Q)3-VEGF } \\
\text { CPG2(Q)3-VEGF } \\
\text { VEGF } 1161-\mathrm{H}_{6}-\mathrm{CPG} 2(\mathrm{Q}) 3-\mathrm{H}_{6} \\
\text { VEGF }_{115}-\mathrm{CPG} 2(\mathrm{Q}) 3-\mathrm{H}_{6}\end{array}$ & 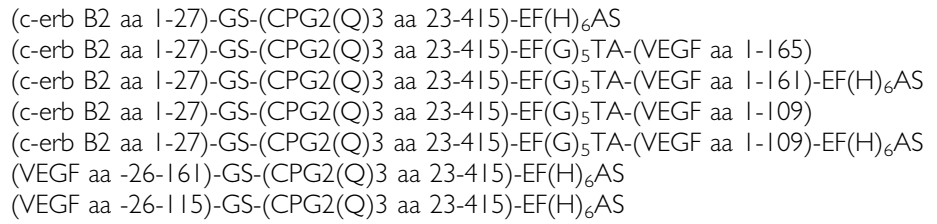 & $\begin{array}{l}43731 \\
62272 \\
63215 \\
55657 \\
57135 \\
61710 \\
56386\end{array}$ & $\begin{array}{l}45000 \\
59-61000 \\
60-62000 \\
53-55000 \\
54-59000 \\
61-63000 \\
55-61000\end{array}$ \\
\hline
\end{tabular}

Sequences of linkers between VEGF and CPG2-derived moieties and of oligohistidine tags for purification by nickel-agarose chromatography are given in the one-letter aminoacid code (22); $M_{r}$ (e), expected relative subunit molecular weight; $M_{r}$ (o), observed subunit molecular weight; aa, amino acids. c-erb B2 aa I-27 encode the c-erb B2 signal peptide. VEGF aa -26-I encode the VEGF signal sequence. 
mobilities (Table 1). In each case, the relative mass was similar to the value that would be predicted from the primary sequence.

\section{Expression and characterisation of VEGF-CPG2 fusion proteins in mammalian cells}

As a first step, CPG2(Q)3-VEGF $165, \mathrm{CPG} 2(\mathrm{Q}) 3-\mathrm{VEGF}_{109}$, and CPG2(Q)3- $\mathrm{H}_{6}$ were transiently expressed (see Table 1, Figure 2) in COS-7 cells. The filtered, conditioned growth media from the cells was tested for CPG2 activity, by examining its ability to hydrolyse the CPG2 substrate methotrexate (MTX). As expected, CPG2 activity was detected in the conditioned growth medium from CPG2(Q)3-VEGF $165, \mathrm{CPG}_{2}(\mathrm{Q}) 3-\mathrm{VEGF}_{109}$, and CPG2(Q)3- $\mathrm{H}_{6}$ expressing cells, but not from control cells expressing $\beta$ galactosidase ( $\beta$-gal)(Figure 3A). There was also detectable CPG2 activity in detergent extracts from these cells (Figure $3 \mathrm{~A}$ ). In Western blotting of the conditioned medium, CPG2 fusion proteins were not detected (data not shown). However, fusion proteins of the expected sizes (see Table 1) were detected in immunoprecipitates of the conditioned medium that used a CPG2 specific antibody to capture the secreted CPG2-fusion proteins (Figure 3B, lanes 2-4). The VEGF moieties of the fusion proteins were then examined for binding to heparin. Conditioned medium from the cells was incubated with heparin-Sepharose, and the heparin-bound proteins were analysed by Western blotting. As expected, only CPG2(Q)3-VEGF 165 bound to heparin-Sepharose (Figure 3C, lane 3), because CPG2(Q)3-VEGF 109 does not contain the heparin-binding domain (Figure $3 c$, lane 4). $\beta$-gal and CPG2(Q) $3-\mathrm{H}_{6}$ also failed to bind to heparin (Figure 3C, lanes 1,2 ).

Next, the expression of the additional fusion proteins was tested. VEGF $_{161}-\mathrm{CPG} 2(\mathrm{Q}) 3-\mathrm{H}_{6}$ and $\mathrm{VEGF}_{115}-\mathrm{CPG} 2(\mathrm{Q}) 3-\mathrm{H}_{6}$ are also secreted and accumulate in growth medium to higher levels than the fusions with the N-terminal CPG2(Q)3 moiety (Table 2). In all cases, the secreted product accumulates to greater amounts in the medium than in the cell extracts (Table 2). $\mathrm{VEGF}_{115}-\mathrm{CPG} 2(\mathrm{Q}) 3-\mathrm{H}_{6}$ is secreted particularly efficiently, with over $98 \%$ of the total expressed activity found in the growth medium. This protein is also the most highly expressed of all the CPG2-VEGF fusion proteins tested. To estimate the specific activity of the CPG2 moiety of the fusion proteins, the concentrations of CPG2 protein in the conditioned media were measured using quantitative Western blotting. The specific activities of the different fusion proteins could then be estimated using the standard enzyme assay. All of the fusion proteins had levels of enzyme activity equivalent to, or higher than the nonfused secreted form of CPG2(Q)3 (CPG2(Q)3- $\mathrm{H}_{6}$; Table 2). Indeed, the fusions with the shorter forms of VEGF both had greater activity (approximately 140\%) than secreted $C P G 2(Q) 3$. However, there does not appear to be any difference in CPG2 activity when the relative orientation of the VEGF- and CPG2-derived moieties is compared. Quantitative Western blotting was also used to determine the relative efficiency of binding of the fusion proteins to heparin-Sepharose as in Table 2. CPG2(Q)3-VEGF 165 and VEGF $_{161}-\mathrm{CPG} 2(\mathrm{Q}) 3-\mathrm{H}_{6}$ both bound to heparin with similar efficiencies, whereas the binding of the fusions with the shorter forms of VEGF was severely reduced (Table 2).

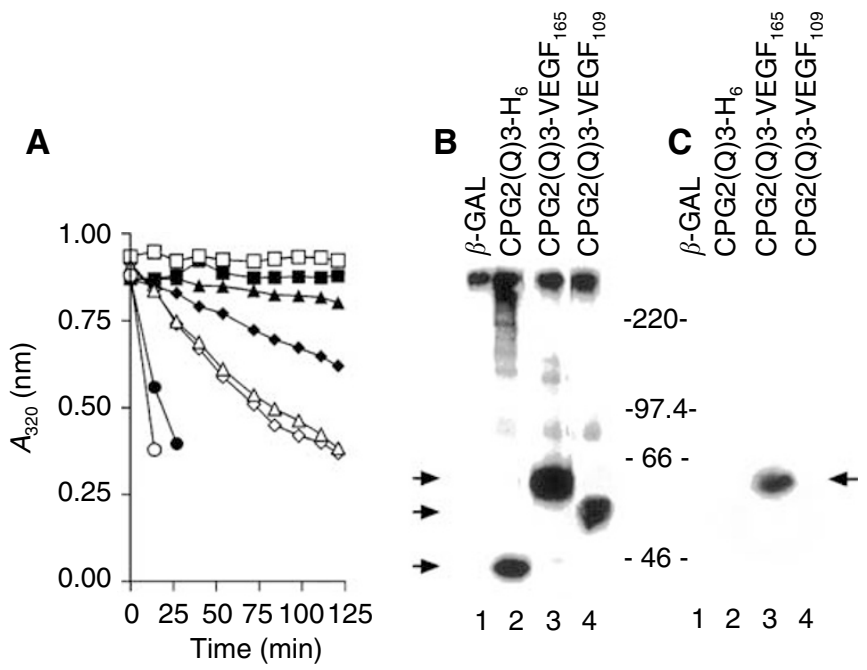

Figure 3 Expression of VEGF-CPG2 fusion proteins in mammalian cells. (A) CPG2 enzyme activity assays. COS-7 cells were transiently transfected with expression constructs for CPG2(Q)3-VEGF $165(\boldsymbol{\Delta}, \triangle)$, CPG(Q)3$\operatorname{VEGF}_{109}(\bullet, \diamond), \mathrm{CPG}_{2}(\mathrm{Q}) 3-\mathrm{H}_{6}(\boldsymbol{\bullet}, \mathrm{O})$ and $\beta$-galactosidase $(\boldsymbol{\square}, \square)$. CPG2 enzyme assays were performed on $\sim 1 / 30$ th of the conditioned growth medium ( $|00 \mu| ; \triangle, \diamond, \square, \bigcirc)$ or detergent cell extracts $(\sim 10 \mu \mathrm{g}$ of protein; $\boldsymbol{\Lambda}, \boldsymbol{\square}, \mathbf{O})$. Data are means of three separate transfections, except for $\beta$-galactosidase expression, which are mean data from two separate transfections. (B) Western blotting of fusion proteins. Proteins from the conditioned medium from COS cells expressing $\beta$-galactosidase ( $\beta$-gal) (lane I), CPG2(Q)3-H 6 (lane 2), CPG2(Q)3-VEGF 165 (lane 3), and CPG(Q)3-VEGF 109 (lane 4) were immunoprecipitated using a polyclonal antibody to CPG2 and subjected to Western blotting for fusion protein expression. The positions of migration of size markers $\left(\times 10^{-3}\right)$ are shown to the right and arrowheads to the left identify the proteins as follows: upper, CPG2(Q)3-VEGF 165 , middle CPG2(Q)3-VEGF 109 , and lower, CPG2(Q) $3-H_{6}$. The figure is a composite of two separate segments of one gel. (C) Heparin binding of VEGF-CPG2 fusion proteins. Conditioned medium from COS-7 cells transiently expressing $\beta$-gal (lane I), CPG2(Q)3$\mathrm{H}_{6}$ (lane 2), CPG2(Q)3-VEGF 165 (lane 3), and CPG2(Q)3-VEGFI09 (lane 4) was analysed for the ability of the fusion proteins to bind to heparinSepharose. Western blotting revealed the bound proteins and the positions of migration of size markers $\left(\times 10^{-3}\right)$ are shown to the left. The arrowhead to the right points towards the position of migration of CPG2(Q)3-VEGF 165 . The figure is a composite of two separate segments of one gel.

Table 2 Expression of fusion proteins between CPG2(Q)3 and VEGF in COS-7 cells

\begin{tabular}{|c|c|c|c|c|}
\hline \multirow[b]{2}{*}{ Protein } & \multicolumn{2}{|c|}{ Total CPG2 activity $\left(\mathrm{U}\right.$ well $\left.^{-1}\right)$ in: } & \multirow{2}{*}{$\begin{array}{c}\text { Relative CPG2-specific } \\
\text { activity (\%) }\end{array}$} & \multirow{2}{*}{$\begin{array}{c}\text { Relative heparin-binding } \\
\text { activity (\%) }\end{array}$} \\
\hline & Cells & Medium & & \\
\hline
\end{tabular}

The CPG2 in conditioned media and cell extracts was measured using quantitative Western blotting to estimate the relative protein levels by phosphorimaging. The relative activity of the different fusion proteins could then be estimated using the standard enzyme assay. Quantitative Western blotting was also used to determine the relative efficiency of binding of the fusion proteins to heparin-Sepharose. Data shown for measurements of total activity and relative activity are means ( \pm s.d.) of three transfections. 


\section{Expression of VEGF-CPG2 fusion proteins in Sf9 cells}

The above data establish that CPG2-VEGF fusion proteins can be produced that retain CPG2 enzyme activity and heparin binding in the VEGF moiety. These fusion proteins were tested for binding to the VEGF receptor, VEGFR2, to ascertain whether they could mediate killing of mammalian cells. To perform these experiments, large amounts of fusion protein were expressed in Sf9 insect cells.

Baculoviruses encoding CPG2(Q)3- $\mathrm{H}_{6}, \mathrm{VEGF}_{115}-\mathrm{CPG} 2(\mathrm{Q}) 3-\mathrm{H}_{6}$, CPG2(Q)3-VEGF $109-\mathrm{H}_{6}$, and $\mathrm{VEGF}_{161}-\mathrm{CPG} 2(\mathrm{Q}) 3-\mathrm{H}_{6}$, were generated and used to infect $\mathrm{Sf} 9$ insect cells. The fusion proteins were purified from conditioned growth media by single-step nickelagarose affinity chromatography, and were judged to be $99 \%$ pure by silver staining (data not shown) except for VEGF 161 -CPG2(Q)3$\mathrm{H}_{6}$, which required an extra heparin affinity chromatography step to reach a similar degree of purity (data not shown).

CPG2 is a homodimeric protein that is denatured by heat treatment in the presence of SDS, and so migrates as monomers in polyacrylamide gels following heat treatment (Spooner et al, 2000). VEGF is also a homodimer, but it is stabilised by disulphide linkage. To assess whether the VEGF moieties were stabilised by disulphide linkages, the different fusion proteins were subjected to heat treatment under reducing or nonreducing conditions. As expected, CPG2(Q)3- $\mathrm{H}_{6}$ migrated as a monomer under both reducing and nonreducing conditions (Figure 4, lanes 1,5). VEGF $_{115}-\mathrm{CPG} 2(\mathrm{Q}) 3-\mathrm{H}_{6}, \quad \mathrm{CPG} 2(\mathrm{Q}) 3-\mathrm{VEGF}_{109}-\mathrm{H}_{6}$, and $\mathrm{VEGF}_{161^{-}}$ $\mathrm{CPG} 2(\mathrm{Q}) 3-\mathrm{H}_{6}$ also migrated as monomers under reducing conditions (Figure 4, lanes 2-4), but under nonreducing conditions migrated with sizes that were consistent with dimerization (Figure 4, lanes 6-8). A contaminating protein, presumably a
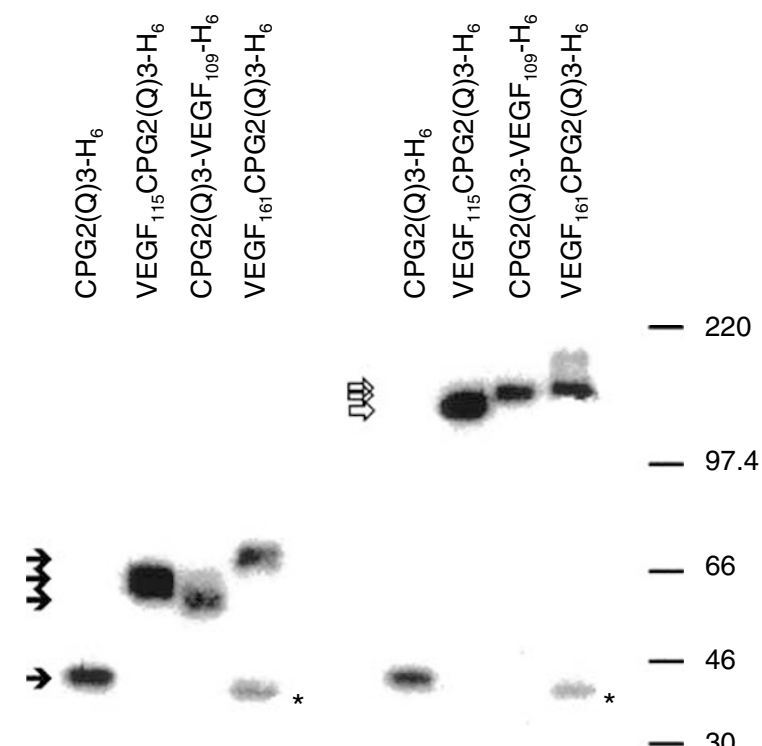

\section{$\begin{array}{llll}1 & 2 & 3 & 4\end{array}$}

Reduced

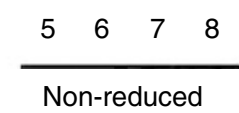

Figure 4 VEGF-CPG2(Q)3 and CPG2(Q)3-VEGF fusion proteins are disulphide-linked dimers. Affinity-purified CPG2(Q)3- $\mathrm{H}_{6}$, VEGF $115^{-}$ CPG2(Q)3- $H_{6}, \quad$ CPG2(Q)3-VEGF $109-H_{6}$, and VEGF $161-C P G 2(Q) 3-H_{6}$ proteins were heated in either reducing (lanes I-4) or nonreducing (lanes 5-8) conditions, subjected to polyacrylamide gel electrophoresis and were identified after immunoblotting using a rabbit anti-CPG2 serum and ${ }^{125}$-Protein $A$. Closed arrowheads show the positions of migration of monomers and open arrowheads show the positions of migration of dimers. The positions of migration of size markers $\left(\times 10^{-3}\right)$ are shown to the right. Asterisks mark the positions of migration of a breakdown product derived from VEGF $161-C P G 2(Q) 3-H_{6}$ protein. degradation product related to $\mathrm{CPG} 2$, is routinely found in preparations of $\mathrm{VEGF}_{161}-\mathrm{CPG} 2(\mathrm{Q}) 3-\mathrm{H}_{6}$ (Figure 4, lanes 4,8$)$. We conclude that the VEGF moieties in these fusion proteins are stabilised by disulphide linkages. These fusion proteins were then tested for the ability to bind to the ligand-binding domain of VEGFR2. For these studies, the extracellular and transmembrane domains of VEGFR2 were expressed as a 9E10-tagged protein in insect cells. This construct, which has the kinase domain (KD) of VEGFR2 deleted, included codons $-20-809$ of VEGFR2 fused to a 9E10 monoclonal antibody epitope (VEGFR2 $(\Delta \mathrm{KD}) \mathrm{m})$.

For VEGF binding studies, VEGFR $2(\Delta \mathrm{KD}) \mathrm{m}$ in a 96 -well plate ELISA format was used. The plates were seeded with the 9E10 monoclonal antibody and VEGFR2 $(\triangle \mathrm{KD}) \mathrm{m}$ was captured on the immobilised $9 \mathrm{E} 10$ antibody. $\left[{ }^{125} \mathrm{I}\right] \mathrm{VEGF}$ bound to this immobilised $\operatorname{VEGFR} 2(\Delta \mathrm{KD}) \mathrm{m}$ with high affinity $\left(K_{\mathrm{d}} \sim 0.5 \mathrm{nM}\right)$. The fusion proteins were incubated with the captured VEGFR $2(\Delta \mathrm{KD}) \mathrm{m}$ and binding was determined. All of the fusion proteins bound with similar affinities, with $K_{\mathrm{d}}$ values of approximately $0.5-1.1 \mathrm{~nm}$ (Figure 5A, Table 3).

A competition RIA was used where binding of $\left[{ }^{125} \mathrm{I}\right]$ VEGF to $\operatorname{VEGFR} 2(\triangle \mathrm{KD}) \mathrm{m}$ occurs in the presence of competing fusion proteins. Using this analysis, the binding of the fusion proteins was estimated to be slightly higher, with $K_{\mathrm{d}}$ values from $1.3-9.6 \mathrm{~nm}$ (Figure 5B, Table 3). CPG2(Q)3- $\mathrm{H}_{6}$ protein did not compete for $\left[{ }^{125}\right.$ I]VEGF binding in this assay (Table 3$)$. Finally, the rate of binding was measured, by exposing the fusion proteins to immobilised VEGFR2 $(\Delta \mathrm{KD}) \mathrm{m}$ for short times before washing out the protein and measuring how much fusion protein was bound. $\mathrm{VEGF}_{115} \mathrm{CPG} 2(\mathrm{Q}) 3-\mathrm{H}_{6}$ reaching half-maximal binding in $77 \mathrm{~s}$ (Figure 5C, Table 3). The binding of CPG2(Q)3VEGF $109-\mathrm{H}_{6}$ and VEGF $_{161} \mathrm{CPG} 2(\mathrm{Q}) 3-\mathrm{H}_{6}$ was somewhat slower, reaching half-maximal binding after about $330 \mathrm{~s}$.

\section{Kinetic analysis of $\operatorname{VEGF}_{115} \mathrm{CPG} 2(\mathrm{Q}) 3-\mathrm{H}_{6}$}

Taken together, the above data suggest that $\operatorname{VEGF}_{115} \mathrm{CPG} 2(\mathrm{Q}) 3-\mathrm{H}_{6}$ is the most suitable candidate for the LiDEPT approach. It displays rapid binding to receptor, is secreted efficiently, is the most highly expressed, and has the highest specific activity. We therefore subjected this protein to detailed kinetic analysis for the CPG2 activity. CPG2 produced in bacteria has a $K_{\mathrm{m}}$ for MTX of $8 \mu \mathrm{M}$ (Sherwood et al, 1985). Similarly, CPG2 expressed in the cytosol of mammalian and insect cells also have $K_{\mathrm{m}}$ values for MTX of approximately $7 \mu \mathrm{M}$ (Napier et al, 2000). Secreted CPG2(Q)3- $\mathrm{H}_{6}$, has a $K_{\mathrm{m}}$ of $29.5 \mu \mathrm{M}$ MTX and $\mathrm{VEGF}_{115}-\mathrm{CPG} 2(\mathrm{Q}) 3-\mathrm{H}_{6}$ a $K_{\mathrm{m}}$ of $37.5 \mu \mathrm{M}$ MTX (mean of two independent preparations). Again, a slight increase in catalytic activity was noted for this fusion protein (140\%, Table 2). Thus, the fusion of VEGF domains to CPG2(Q)3 does not appear to affect the affinity for substrate as compared to secreted $\mathrm{CPG} 2(\mathrm{Q}) 3$, and can result in a moderate increase in catalytic activity.

\section{Fusion proteins of CPG2 and VEGF can direct cytotoxicity to VEGFR2-positive cells}

VEGF-CPG2 fusion proteins were next assessed for their ability to generate a targeted increase in the cytotoxicity of CMDA towards HU-V-EC cells, which express receptors for VEGF. Initially, the sensitivity of HU-V-EC cells to CMDA alone was established. The $\mathrm{IC}_{50}$ of CMDA in HU-V-EC cells was 1587 ( \pm ) $224 \mu \mathrm{M}$ (Figure 6A). The highest dose of CMDA that produced no cytotoxicity in HU-VEC cells was $500 \mu \mathrm{M}$ (open arrowhead, Figure 6A).

Confluent HU-V-EC cells were incubated with three doses of VEGF $_{115}-\mathrm{CPG} 2(\mathrm{Q}) 3-\mathrm{H}_{6}, \mathrm{CPG} 2(\mathrm{Q}) 3-\mathrm{VEGF}_{109}-\mathrm{H}_{6}$, or CPG2(Q)3- $\mathrm{H}_{6}$ $(50,5$, or $0.5 \mathrm{nM})$ in complete growth medium for $30 \mathrm{~min}$, after which the unbound proteins were removed by rinsing $\times 3$. These cells were then incubated in the previously established nontoxic dose of CMDA $(500 \mu \mathrm{M})$, and cell survival then determined in our 


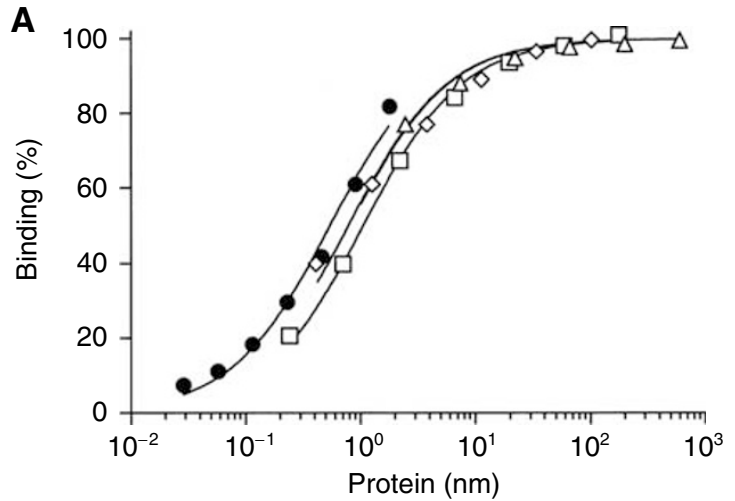

B
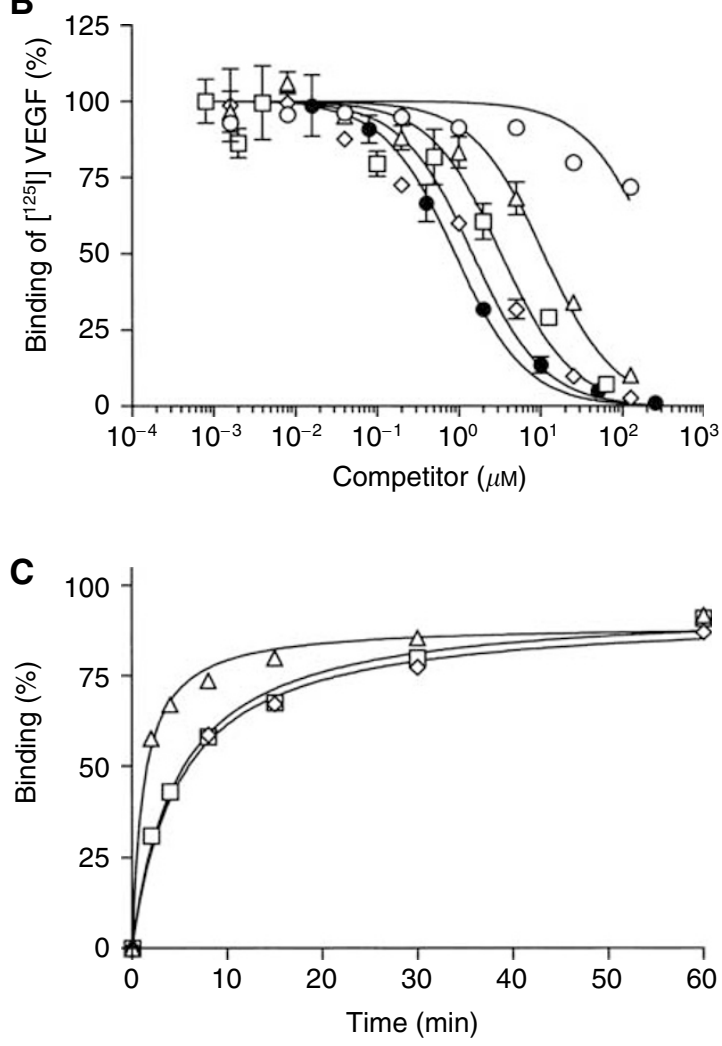

Figure 5 In vitro binding assays: (A) ELISA showing binding of [ ${ }^{125}$ I]VEGF

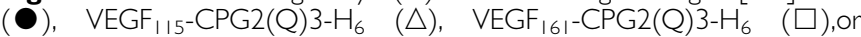
CPG2(Q)3-VEGF $109-\mathrm{H}_{6}(\diamond)$ to VEGFR2 $(\Delta K D) \mathrm{m}$. (B) RIA showing competition of $\mathrm{CPG}_{2}(\mathrm{Q}) 3-\mathrm{H}_{6}(\mathrm{O})$, VEGF ${ }_{115}-\mathrm{CPG}_{2}(\mathrm{Q}) 3-\mathrm{H}_{6}(\triangle)$, $V E_{161}-C P G 2(Q) 3-H_{6}(\square), C$ CPG2(Q)3-VEGF $109-H_{6}(\diamond)$, or VEGF 165 (-) with [ ${ }^{125}$ I]VEGF for VEGFR2 $(\triangle \mathrm{KD}) \mathrm{m}$. (C) Kinetics of binding of $V_{V G F}{ }_{15}-C P G 2(Q) 3-H_{6}(\triangle), V^{2} F_{161}-C P G 2(Q) 3-H_{6}(\square)$,or CPG2(Q)3VEGF $109-\mathrm{H}_{6}(\diamond)$ to VEGFR2 $(\Delta K D) m$ captured by immobilised 9 EIO monoclonal antibody, measured by ELISA.

standard assay. Only a slight increase in cytotoxicity was seen with increasing concentrations of $\mathrm{CPG} 2(\mathrm{Q}) 3-\mathrm{H}_{6}$ (Figure 6B). By contrast, a marked protein-dose-dependant reduction in survival was seen following exposure to $\mathrm{VEGF}_{115}-\mathrm{CPG} 2(\mathrm{Q}) 3-\mathrm{H}_{6}$, and VEGF $_{109}-\mathrm{CPG} 2(\mathrm{Q}) 3-\mathrm{H}_{6}$, indicative of these proteins having resisted rinsing, being bound, presumably to the VEGFRs of the cells. To confirm that this increased cytotoxicity is indeed the result of binding to VEGFRs, a similar experiment was performed, comparing HU-V-EC cells to SK-OV-3 cells, which by contrast do not express VEGFRs. As previously, the sensitivity to CMDA alone was first established. The $\mathrm{IC}_{50}$ of CMDA in SK-OV-3 cells was
$4323( \pm 473) \mu \mathrm{M}$ (Figure $6 \mathrm{~A})$ very similar to our previous estimate (Marais et al, 1997). The highest dose of CMDA that produced no cytotoxicity in SK-OV-3 cells was $1000 \mu \mathrm{M}$ (filled arrowhead, Figure 6A). HU-V-EC and SK-OV-3 cells were treated with $50 \mathrm{~nm}$ VEGF $_{115}-\mathrm{CPG} 2-\mathrm{H}_{6}$, washed three times, and then treated with subcytotoxic doses of CMDA (500 and $1000 \mu \mathrm{M}$, respectively). This results in an increase in cytotoxicity (75\%) in HU-V-EC cells, but not in SK-OV-3 cells (Figure 6), confirming that the fusion protein is binding to VEGFRs on HU-V-EC cells.

Thus, the cytotoxic drug is being generated from concentrations of CMDA similar to those achieved in the plasma of human patients during a phase I/II ADEPT clinical trial (Martin et al, 1997).

\section{Stability of fusion protein in vivo}

When VEGF $_{115}-\mathrm{CPG}_{2}-\mathrm{H}_{6}$ was injected i.p. into mice, the plasma levels of enzymic CPG2 activity decayed with a one-phase exponential half-life of $3 \mathrm{~h}$ (Figure 7), similar to that previously observed $(4 \mathrm{~h})$ with an antibody fragment-CPG2 conjugate, known as A5B7-F(ab')2-CPG2, used in ADEPT (Sharma et al, 1990). The presence of enzymic activity implies the presence of intact dimers, and we anticipate that this stability in the circulation will also allow localisation similar to that seen in ADEPT (Napier et al, 2000), a therapy now in phase I/II trial.

\section{DISCUSSION}

The approach of targeting cytotoxicity via a fusion protein has a long and successful history. Prime examples are the fusions of cellbinding ligands with the catalytic subunit of Pseudomonas exotoxin A, which lacks cell-binding activity. The first example was fusion with transforming growth factor-type alpha (Chaudhary et al, 1987). Since then, a wide range of fusion partners have been considered, including interleukins (Chaudhary et al, 1989; Batra et al, 1991, 1992; Kreitman et al, 1992; Gawlak et al, 1993; Kunwar et al, 1993; Francisco et al, 1995; Siegall et al, 1995), other growth factors (Prior et al, 1991; Gawlak et al, 1993; Kunwar et al, 1993; Mesri et al, 1993; Siegall et al, 1995), single chain antibody fragments (Chaudhary et al, 1989; Batra et al, 1991, 1992; Kreitman et al, 1992; Francisco et al, 1995) and hormones (Ben Yehudah et al, 1999). Such studies have demonstrated that a wide range of ligands can be regarded as potential antitumour-targeting devices, and a wide range of cellular receptors can be viewed as targets. Furthermore, complete regressions have been recorded (Brinkmann et al, 1991), underlining the success of this approach.

We considered the VEGFRs as targets for an approach to deliver not a toxin, but an enzyme with catalytic activity capable of converting large numbers of molecules of a nontoxic prodrug to a toxic drug. We show that VEGF-CPG2 fusion proteins retain activities of both parental molecules, irrespective of whether they are the $\mathrm{N}$ - or C-terminal moiety, and that they retain these characteristics if either very short or longer linkers are used to join them. If provided with either the VEGF signal sequence or the cerb B2 signal sequence, all the fusions are secreted into the growth medium, from where they could be purified to near homogeneity by single-step nickel-agarose chromatography. All the fusions are disulphide-linked dimers as expected. Those with shorter VEGF moieties show a moderate (1.4-fold) increase in CPG2 activity. Native CPG2 is active as a dimeric protein, while CPG2(Q)3 has a comparatively reduced activity owing to a reduction in dimer stability (Spooner et al, 2000). It is therefore possible that fusion with the shorter forms of VEGF compensates for the deleterious effect of the (Q)3 mutations by improving dimer stability. These fusion proteins bind VEGFR2 domains with an affinity close to that of VEGF, and one in particular, VEGF $_{115}-\mathrm{CPG}_{2}(\mathrm{Q}) 3-\mathrm{H}_{6}$ binds very rapidly. It retains specificity for VEGFR2, and can 
Table 3 Binding characteristics of fusion proteins between CPG2(Q)3 and VEGF expressed in insect cells

\begin{tabular}{|c|c|c|c|}
\hline Protein & ELISA $K_{d}(n M)$ & Competition RIA $K_{\mathrm{d}}(\mathrm{nM})$ & $50 \%$ binding $t_{50}(s)$ \\
\hline $\begin{array}{l}\text { CPG2(Q)3-VEGF } 109-H_{6} \\
\text { VEGF } 161-C P G 2(Q) 3-H_{6} \\
V_{15 G}-C P G 2(Q) 3-H_{6} \\
\text { CPG2(Q)3-H } \\
{\left[{ }^{125} \mid\right]-V E G F}\end{array}$ & $\begin{array}{c}0.75( \pm 0.05) \\
1.06( \pm 0.66) \\
0.51( \pm 0.08) \\
N D \\
0.51( \pm 0.06)\end{array}$ & $\begin{array}{c}1.3( \pm 0.1) \\
3.3( \pm 0.3) \\
9.6( \pm 0.6) \\
\text { No competition } \\
\text { ND }\end{array}$ & $\begin{array}{r}332 \\
330 \\
77 \\
\text { ND } \\
\text { ND }\end{array}$ \\
\hline
\end{tabular}

VEGFR2 $(\Delta K D) m$ was captured on the $9 E 10$ antibody immobilised in 96-well plates. The fusion proteins were incubated with the captured VEGFR2( $\Delta$ KD)m and binding was determined. We also used a competition RIA where binding of [ ${ }^{125}$ I]VEGF to VEGFR2( $\left.\Delta K D\right) m$ occurs in the presence of competing fusion proteins. The rate of binding was also determined, by exposing the fusion proteins to immobilised VEGFR2 $\Delta K D) m$ for short times before washing out the protein and measuring how much fusion protein was bound.
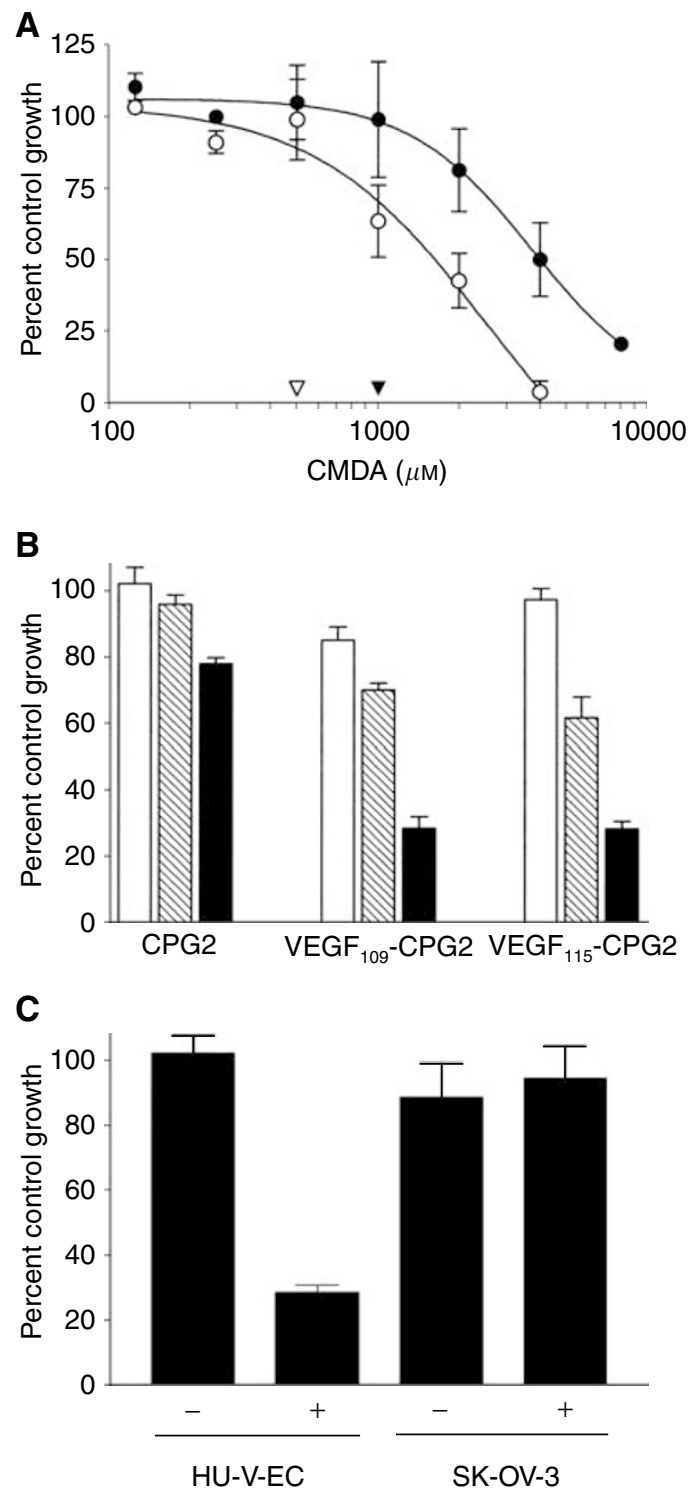

Figure 6 Cytotoxicity studies. (A) Sensitivity of HU-V-EC $(O)$ and SKOV-3 cells $(\mathbf{O})$ to treatment with the prodrug CMDA. Arrowheads show the maximum concentrations of CMDA that the HU-V-EC $(\nabla)$ and SKOV-3 cells $(\boldsymbol{\nabla})$ cells can tolerate without measurable cell death. (B) Effect on the survival of HU-V-EC cells of preincubation with CPG2(Q)3- $\mathrm{H}_{6}$ CPG2(Q)3-VEGFI09- $\mathrm{H}_{6}$, or VEGFI I SCPG2(Q)3- $\mathrm{H}_{6}$, at doses of $0.5 \mathrm{~nm}$ (plain bars), $5 \mathrm{~nm}$ (shaded bars), or $50 \mathrm{~nm}$ (filled bars) and subsequent treatment with $500 \mu \mathrm{M}$ CMDA. (C) Sensitivity of HU-V-EC and SK-OV-3 cells to CMDA challenge (500 and I000 $\mu \mathrm{M}$, respectively) after a $30 \mathrm{~min}$ incubation with $50 \mathrm{~nm}$ VEGF $_{1 / 5} \mathrm{CPG} 2(\mathrm{Q}) 3-\mathrm{H}_{6}$.

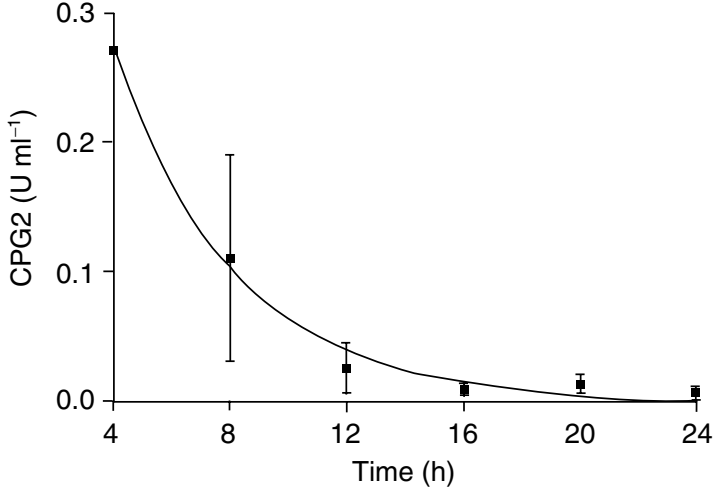

Figure 7 Balb/c nude mice were injected i.p. with $50 \cup$ CPG2. At intervals as indicated, blood was collected and analysed for CPG2 activity. The line is a fit to a one-phase exponential decay with a half-life of $2.8 \mathrm{~h}$ Each point represents the mean of three separate determinations \pm s.e.m.

differentiate between endothelial cells that express VEGFRs (HU$\mathrm{V}-\mathrm{EC}$ ) and those that do not (SK-OV-3). Once delivered to cells, the proteins can convert the prodrug CMDA to its toxic metabolite, thus killing targeted cells.

Although expression of VEGFR2 is high in the neoangiogenic regions of tumour vasculature, some normal organs also express VEGFRs (Blaauwgeers et al, 1999; Kim et al, 1999). Both receptors are expressed predominantly in endothelial cells, but a few additional cell types express one or both of these receptors. Despite these caveats, recognition of VEGFRs as therapeutic targets for cancer is likely to be of value. Indeed, VEGF-diphtheria toxin fusion proteins are toxic to endothelial cells and Kaposi's sarcoma cell lines, inhibit angiogenesis and retard tumour growth, in a VEGFR-dependent manner (6). Since nearly all tumours induce local angiogenesis with associated high levels of VEGFR expression, VEGF-derived targeting molecules may have wide application for therapy.

VEGF-CPG2 fusion proteins should direct CPG2 activity to cells expressing VEGFRs, principally those activated endothelial cells in tumour vasculature. Once localised, these proteins can convert a nontoxic prodrug into a cytotoxic drug, thus providing targeted cell death of tumour neovasculature. Such a strategy might be expected to lead to cell death of targeted cells, plus a 'bystander' component of neighbouring nontargeted cells killed by high concentrations of soluble drug near the targeted cells, and perhaps associated with a further bystander effect via ischaemia. Since halting angiogenesis suppresses carcinoma cell invasion (Skobe et al, 1997), VEGFR-targeted CPG2 might also reduce spread of the disease. The features of the VEGF-CPG2 fusion proteins we describe here suggest that targeted therapy by LiDEPT is a feasible strategy for the targeting of activated endothelial cells in a tumour. 
In summary, we have developed a VEGF $115-\mathrm{CPG} 2(\mathrm{Q}) 3-\mathrm{H}_{6}$ fusion protein that is highly expressed, efficiently secreted, has a high specific activity, binds rapidly to its target, can direct prodrug cytotoxicity to VEGFR2-expressing cells, and is a candidate for a new approach to cancer therapy.

\section{REFERENCES}

Arora N, Masood R, Zheng T, Cai J, Smith DL, Gill PS (1999) Vascular endothelial growth factor chimeric toxin is highly active against endothelial cells. Cancer Res 59: $183-188$

Bagshawe KD (1990) Antibody-Directed Enzyme Prodrug Therapy (ADEPT). Biochem Soc Trans 18: 750-752

Bagshawe KD, Sharma SK, Springer CJ, Antoniw P, Boden JA, Rogers GT, Burke PJ, Melton RG, Sherwood RF (1991) Antibody Directed Enzyme Prodrug Therapy (ADEPT) - Clinical Report. Dis Markers 9: 233-238

Batra JK, FitzGerald DJ, Chaudhary VK, Pastan I (1991) Single-chain immunotoxins directed at the human transferrin receptor containing pseudomonas exotoxin-A or diphtheria-toxin - anti-TFR(Fv)-PE40 and DT388-anti-TFR(Fv). Mol Cell Biol 11: 2200-2205

Batra JK, Kasprzyk PG, Bird RE, Pastan I, King CR (1992) Recombinant anti-erbB2 immunotoxins containing pseudomonas exotoxin. Proc Natl Acad Sci 89: $5867-5871$

Ben Yehudah A, Yarkoni S, Nechushtan A, Belostotsky R, LorberboumGalski H (1999) Linker-based GnRH-PE chimeric proteins inhibit cancer growth in nude mice. Med Oncol 16: $38-45$

Blaauwgeers HGT, Holtkamp GM, Rutten H, Witmer AN, Koolwijk P, Partanen TA, Alitalo K, Kroon ME, Kijlstra A, van-Hinsbergh VWM, Schlingemann RO (1999) Polarized vascular endothelial growth factor secretion by human retinal pigment epithelium and localization of vascular endothelial growth factor receptors on the inner choriocapillaris. Evidence for a trophic paracrine relation. Am J Pathol 155: 421-428

Brinkmann U, Pai LH, FitzGerald DJ, Willingham M, Pastan I (1991) B3(Fv)-PE38KDEL, a single-chain immunotoxin that causes complete regression of a human carcinoma in mice. Proc Natl Acad Sci 88: 86168620

Chaudhary VK, FitzGerald DJ, Adhya S, Pastan I (1987) Activity of a recombinant fusion protein between transforming growth-factor typealpha and pseudomonas toxin. Proc Natl Acad Sci 84: 4538-4542

Chaudhary VK, Queen C, Junghans RP, Waldmann TA, FitzGerald DJ, Pastan I (1989) A recombinant immunotoxin consisting of 2 antibody variable domains fused to pseudomonas exotoxin. Nature 339: 394-397

Evan GI, Lewis GK, Ramsay G, Bishop JM (1985) Isolation of monoclonalantibodies specific for human C-MYC proto-oncogene product. Mol Cell Biol 5: $3610-3616$

Fidler IJ, Ellis LM (1994) The implications of angiogenesis for the biology and therapy of cancer metastasis. Cell 79: 185-188

Folkman J (1995) Clinical applications of research in angiogenesis. N Engl J Med 333: $1757-1763$

Francisco JA, Gilliland LK, Stebbins MR, Norris NA, Ledbetter JA, Siegall CB (1995) Activity of a single-chain immunotoxin that selectively kills lymphoma and other B-lineage cells expressing the CD40 antigen. Cancer Res 55: 3099-3104

Frei E, Teicher BA, Holden SA, Cathcart KNS, Wang YY (1988) Preclinical studies and clinical correlation of the effect of alkylating dose. Cancer Res 48: $6417-6423$

Fukumura D, Xavier R, Sugiura T, Chen Y, Park E-C, Lu N, Selig M, Nielsen G, Taksir T, Jain RK, Seed B (1998) Tumor induction of VEGF promoter activity in stromal cells. Cell 94: 715-725

Gawlak SL, Pastan I, Siegall CB (1993) Basic fibroblast growth factorpseudomonas exotoxin chimeric proteins - comparison with acidic fibroblast growth factor-pseudomonas exotoxin. Bioconjug Chem 4: $483-489$

Ho SN, Hunt HD, Horton RM, Pullen JK, Pease LR (1989) Site-directed mutagenesis by overlap extension using the polymerase chain-reaction. Gene 77: $51-59$

Hogg PJ, Johnston SC, Bowles MR, Pond SM, Winzor DJ (1987) Evaluation of equilibrium-constants for antigen-antibody interactions by solidphase immunoassay - the binding of paraquat to its elicited mouse monoclonal-antibody. Mol Immunol 24: 797-801

Houck KA, Ferrara N, Winer J, Cachianes G, Li B, Leung DW (1991) The vascular endothelial growth-factor family - identification of a 4 th

\section{ACKNOWLEDGEMENT}

We thank Cancer Research UK for part funding this work (Grant no. SP2330/0201). molecular-species and characterization of alternative splicing of DNA. Mol Endocrinol 5: $1806-1814$

Keyt BA, Berleau LT, Nguyen HV, Chen H, Heinsohn H, Vandlen R, Ferrara $\mathrm{N}$ (1996) The carboxyl-terminal domain (111-165) of vascular endothelial growth factor is critical for its mitogenic potency. J Biol Chem 271: $7788-7795$

Kim I, Ryan AM, Rohan R, Amano S, Agular S, Miller JW, Adamis AP (1999) Constitutive expression of VEGF, VEGF-1, and VEGFR-2 in normal eyes. Invest Ophthalmol Vis Sci 40: 2115-2121

Kreitman RJ, Schneider WP, Queen C, Tsudo M, FitzGerald DJP, Waldmann TA, Pastan I (1992) Mik-beta 1(Fv)-PE40, a recombinant immunotoxin cytotoxic toward cells bearing the beta-chain of the IL-2 receptor. J Immunol 149: $2810-2815$

Kunwar S, Pai LH, Pastan I (1993) Cytotoxicity and antitumor effects of growth factor-toxin fusion proteins on human glioblastoma-multiforme cells. J Neurosurg 79: 569-576

Leung DW, Cachianes G, Kuang WJ, Goeddel DV, Ferrara N (1989) Vascular endothelial growth-factor is a secreted angiogenic mitogen. Science 246: $1306-1309$

Marais R, Spooner RA, Light Y, Martin J, Springer CJ (1996) Gene-directed enzyme prodrug therapy with a mustard prodrug/carboxypeptidase G2 combination. Cancer Res 56: 4735-4742

Marais R, Spooner RA, Stribbling SM, Light Y, Martin J, Springer CJ (1997) A cell surface tethered enzyme improves efficiency in gene-directed enzyme prodrug therapy. Nat Biotech 15: 1373-1377

Martin J, Stribbling SM, Poon GK, Begent RHJ, Napier M, Sharma SK, Springer CJ (1997) Antibody-directed enzyme prodrug therapy: pharmacokinetics and plasma levels of prodrug and drug in a phase I clinical trial. Cancer Chemotherapy Pharmacol 40: 189-201

Mesri EA, Kreitman RJ, Fu YM, Epstein SE, Pastan I (1993) Heparinbinding transforming growth-factor alpha-pseudomonas exotoxin-A. A heparan sulphate-modulated recombinant toxin cytotoxic to cancercells and proliferating smooth-muscle cells. J Biol Chem 268: 4853-4862

Napier MP, Sharma SK, Springer CJ, Bagshawe KD, Green AJ, Martin J, Stribbling SM, Cushen N, O'Malley D, Begent RH (2000) Antibodydirected enzyme prodrug therapy: efficacy and mechanism of action in colorectal carcinoma. Clin Cancer Res 6: 765-772

Niculescu-Duvaz I, Niculescu-Duvaz D, Friedlos F, Spooner R, Martin J, Marais R, Springer CJ (1999) Self-immolative anthracycline prodrugs for suicide gene therapy. I Med Chem 42: 2485-2489

Poltorak Z, Cohen T, Sivan R, Kandelis Y, Spira G, Vlodavsky I, Keshet E, Neufeld G (1997) VEGF(145), a secreted vascular endothelial growth factor isoform that binds to extracellular matrix. J Biol Chem 272: 7151-7158

Prior TI, Helman LJ, FitzGerald DJ, Pastan I (1991) Cytotoxic activity of a recombinant fusion protein between insulin-like growth factor-I and pseudomonas exotoxin. Cancer Res 51: 174-180

Sharma SK, Bagshawe KD, Burke PJ, Boden JA, Rogers GT (1990) Inactivation and clearance of an anti-CEA carboxypeptidase G2 conjugate in blood after localisation in a xenograft model. Br J Cancer 61: $659-662$

Sherwood RF, Melton RG, Alwan SM, Hughes P (1985) Purification and properties of carboxypeptidase G2 from pseudomonas sp. Strain RS-16 - use of a novel triazine dye affinity method. Eur J Biochem 148: $447-453$

Siegall CB, Bacus SS, Cohen BD, Plowman GD, Mixan B, Chace D, Chin DM, Goetze A, Green JM, Hellstrom I, Hellstrom KE, Fell HP (1995) HER4 expression correlates with cytotoxicity directed by a heregulin-toxin fusion protein. I Biol Chem 270: 7625-7630

Skobe M, Rockwell P, Goldstein N, Vosseler S, Fusenig NE (1997) Halting angiogenesis suppresses carcinoma cell invasion. Nat Med 3: $1222-1227$

Spooner RA, Martin J, Friedlos F, Marais R, Springer CJ (2000) In suicide gene therapy, the site of subcellular localisation of the activating enzyme is more important than the rate at which it activates prodrug. Cancer Gene Therapy 7: $1348-1356$ 
Springer CJ (1993) CMDA, an antineoplastic drug. Drugs Future 18: $212-215$

Springer CJ, Dowell R, Burke PJ, Hadley E, Davies DH, Blakey DC, Melton RG, Niculescu-Duvaz I (1995) Optimization of alkyating agent prodrugs derived from phenol and aniline mustards: a new clinical candidate prodrug (ZD2767P) for antibody-directed enzyme prodrug therapy (ADEPT). J Med Chem 38: 5051-5065

Stribbling SM, Friedlos F, Martin J, Davies L, Spooner RA, Marais R, Springer CJ (2000) Regressions of established breast carcinoma xenografts by carboxypeptidase G2 suicide gene therapy and the prodrug CMDA are due to a bystander effect. Hum Gene Ther 11: 285-292

Stribbling SM, Martin J, Pedley RB, Boden JA, Sharma SK, Springer CJ (1997) Biodistribution of an antibody-enzyme conjugate for ADEPT in

nude mice bearing a human colon adenocarcinoma xenograft. Cancer Chemotherapy Pharmacol 40: $277-284$

Teicher BA, Frei E (1988) Development of alkylating agent-resistant human- tumor cell-lines. Cancer Chemotherapy Pharmacol 21: 292-298 Tischer E, Gospodarowicz D, Mitchell R, Silva M, Schilling J, Lau K, Crisp T, Fiddes JC, Abraham JA (1989) Vascular endothelial growth-factor - a new member of the platelet-derived growth factor gene family. Biochem Biophys Res Commun 165: 1198-1206

Workman P, Twentyman P, Balkwill F, Balmain A, Chaplin D, Double J, Embleton J, Newell D, Raymond R, Stables J, Stephens T, Wallace J (1998) United Kingdom Co-ordinating Committee on Cancer Research (UKCCCR) guidelines for the welfare of animals in Experimental Neoplasia (second edition). Br J Cancer 77: 1 - 10 